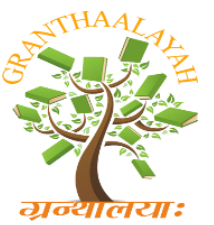

$$
\begin{gathered}
\text { INTERNATIONAL JOURNAL OF RESEARCH - } \\
\text { GRANTHAALAYAH } \\
\text { A knowledge Repository }
\end{gathered}
$$

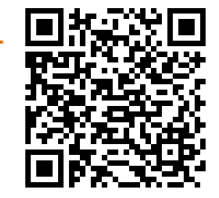

\title{
EFFECT OF CARBON DI SULPHIDE ON GERMINATION OF RABI CROP OF NAGDA TOWN
}

\author{
Archana Kushwaha \\ Government College, Nagda (M.P)
}

\begin{abstract}
Carbon disulfide is a colorless volatile liquid with the formula CS2. The compound is used frequently as a building block in organic chemistry as well as an industrial and chemical non-polar solvent It is widely used in the synthesis of organosulfur compounds and is commonly used in the production of the soft fabric viscose. Carbon disulfide evaporates rapidly when released to the environment. Carbon disulfide does not stay dissolved in water very long, and it also moves quickly through soils. Soil $\mathrm{pH}$ directly affects the life and growth of plants because it affects the availability of all plant nutrients. Between $\mathrm{pH} 6.0$ to 6.5 most plant nutrients are in their most available state. In present study the rate of germination of rabi crop was monitored. Black cotton soil from different areas of Nagda town was taken for germination of sample seeds .The study was focused on different field of Nagda. It was found that the field of Nagda town was not appropriate for seed germination. Rate of germination was found poor in comparison to other field.
\end{abstract}

Keywords:

Carbon disulfide, Rabi, Germination, Soil.

\section{INTRODUCTION}

Carbon disulfide is a colorless volatile liquid with the formula $\mathrm{CS}_{2 .}{ }^{1-10}$ the compound is used frequently as a building block in organic chemistry as well as an industrial and chemical non-polar solvent. It has an "ether-like" odor, but commercial samples are typically contaminated with foulsmelling impurities, such as carbonyl sulfide. Compared to $\mathrm{CO}_{2}, \mathrm{CS}_{2}$ is more reactive toward nucleophiles and more easily reduced. These differences in reactivity can be attributed to the weaker $\pi$ donor-ability of the sulfido centers, which renders the carbon more electrophilic. It is widely used in the synthesis of organosulfur compounds and is commonly used in the production of the soft fabric viscose. At high levels, carbon disulfide may be life-threatening because it affects the nervous system. Significant safety data comes from the viscose rayon industry, where both carbon disulfide as well as small amounts of $\mathrm{H} 2 \mathrm{~S}$ may be present. Carbon disulfide breaks down into other chemical substances after it enters the body. Medical tests can measure levels of these substances in urine and blood, but the tests are not reliable indicators of total exposure.

Acute (short-term) ecological effects: Acute toxic effects may include the death of animals, birds, or fish, and death or low growth rate in plants. Acute effects are seen two to four days after animals or plants are exposed to a toxic chemical substance. Carbon disulfide has moderate acute toxicity 
to aquatic life. No data are available on the short-term effects of carbon disulfide to plants, birds, or land animals.

Chronic (long-term) ecological effects: Chronic toxic effects may include shortened lifespan, reproductive problems, lower fertility, and changes in appearance or behavior. Chronic effects can be seen long after first exposure to a toxic chemical. Carbon disulfide has high chronic toxicity to aquatic life. No data are available on the long-term effects of carbon disulfide to plants, birds, or land animals.

\section{ENTERING THE ENVIRONMENT}

Carbon disulfide evaporates rapidly when released to the environment. Carbon disulfide does not stay dissolved in water very long, and it also moves quickly through soils.

Carbon disulfide reacts with the hydroxyl $(\mathrm{OH})$ radical in the atmosphere, with the effective rate constant depending on $\mathrm{O} 2$ concentration and total pressure. Based on the literature rate constant at one atmosphere of air, the calculated half-life of carbon disulfide due to its reaction with the $\mathrm{OH}$ radical are about 8 days. Its reaction products include carbonyl sulfide and sulfur dioxide

Carbon disulfide is non-persistent in water, with a half-life of less than 2 days. About $99.8 \%$ of carbon disulfide will eventually end up in air; the rest will end up in the water.

Nagda is a city in Ujjain district in the Indian state of Madhya Pradesh. It is an industrial town in the Malwa region of western Madhya Pradesh and is situated on the bank of Chambal River.

Nagda is a major industrial town having manufacturing unit of Viscose fiber, thermal power plant and a chemical plant,

.Fertile black soils are found in the Malwa Plateau Agriculture is the basis of Madhya Pradesh's economy. The most important crops are wheat, sorghum (jowar), corn (maize), rice, and pulses (legumes such as peas, beans, or lentils) wheat and sorghum are more important. The state is one of the largest producers of soybeans in India. Other crops include linseed, sesame, sugarcane, and cotton, as well as various millets, which are grown in hilly areas. The black soils found in the lavacovered areas are the most conspicuous. These soils are popularly known as "black cotton soils, Because of their high clay content, black soils develop wide cracks during the dry season, but their iron-rich granular structure makes them resistant to wind and water erosion. They are poor in humus yet highly moisture-retentive, thus responding well to irrigation

Soil $\mathrm{pH}$ directly affects the life and growth of plants because it affects the availability of all plant nutrients. Between pH 6.0 to 6.5 most plant nutrients are in their most available state. A nutrient must be soluble and remain soluble long enough to successfully travel through the soil solution into the roots. Nitrogen has its greatest solubility between soil $\mathrm{pH} 4-8$. Above or below that range, its solubility is seriously restricted. Soil acidity or alkalinity is very important because it has effect on the decomposition of mineral rock into essential elements that plant can use. It also changes fertilizers from their form in the bag to a form that plants can easily uptake. Soil micro-organisms that change organic nitrogen (amino acids) to the ammonium form of nitrogen to the nitrate form that plant can use also depends on the soil $\mathrm{pH}$. In present study the rate of germination of Rabi crop was monitored. Black cotton soil from different areas of Nagda town was taken for germination of sample seeds. The study was focused on different field of Nagda. It was found that the field of Nagda ground was not appropriate for seed germination. Rate of germination was found poor in comparison to other field. 


\section{METHODOLOGY}

In present study the rate of germination was monitored by the comparing the field of Nagda which are near the exposure of carbon di sulphide and the field of remote area. Different sample were taken and they were given no 1 to 6 and the rate of germination were monitored in different field. Field no 1,2 and 3 were the fields those were near the exposure of CS2 \& field NO 4,5\& 6 were situated in remote area.

\section{RESULTS AND DISCUSSION}

$\%$ RATE OF GERMINATION OF DIFFERENT FIELD

\begin{tabular}{|l|l|l|l|l|l|l|}
\hline SAMPLE & FIELD & FIELD & FIELD & FIELD & FIELD & FIELD \\
& 01 & 02 & 03 & 04 & 05 & 06 \\
\hline 1 & 70 & 71 & 72 & 82 & 80 & 79 \\
\hline 2 & 69 & 69 & 72 & 83 & 88 & 81 \\
\hline 3 & 71 & 72 & 69 & 75 & 76 & 81 \\
\hline 4 & 75 & 73 & 77 & 74 & 78 & 73 \\
\hline 5 & 76 & 71 & 69 & 78 & 77 & 79 \\
\hline 6 & 78 & 70 & 70 & 77 & 85 & 89 \\
\hline AVERAGE & 73.16 & 71 & 71.5 & 78.16 & 80.66 & 80.33 \\
\hline
\end{tabular}

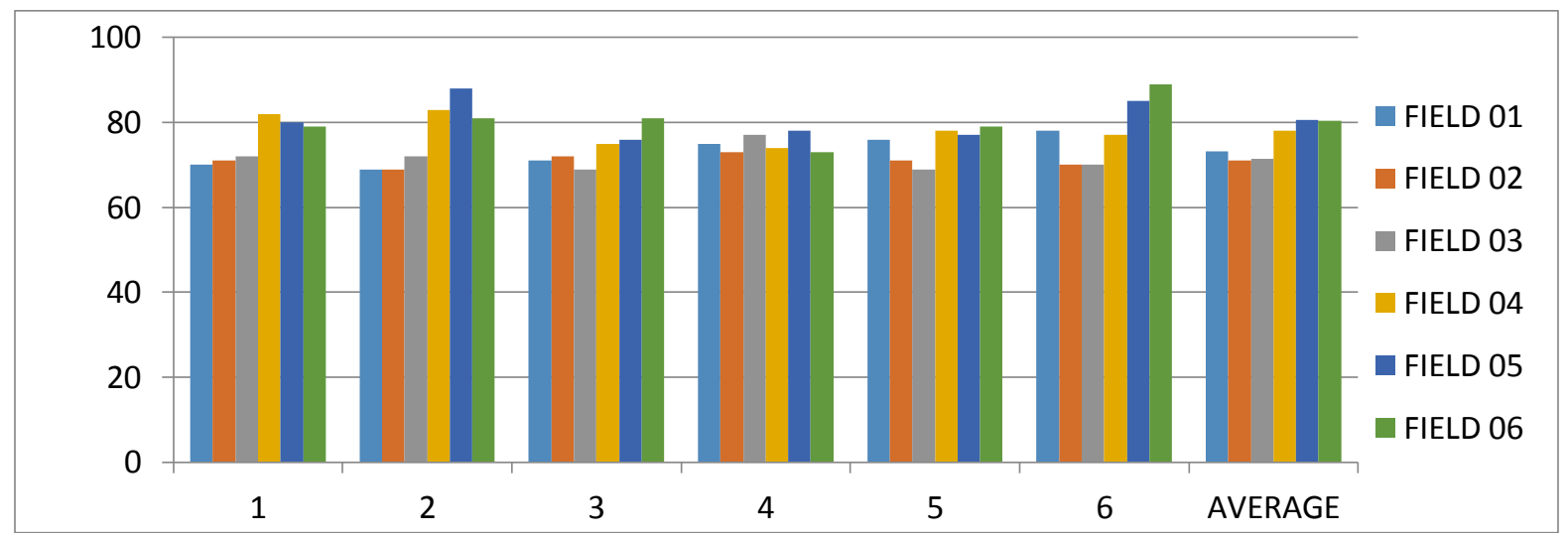

It was found that the \% rate of germination was good enough of the field of remote area that is field no 4,5and 6 . The soil of these fields are more fertile than those of situated near the exposure of CS2 field no 1,2 and 3 .

\section{CONCLUSION}

Our country is developing nowadays .Industries are the major part of development. Increase in population jobs are also needed .Industries are providing the jobs but some environmental issues are there. In present study the effect of carbon di sulphide on the rate of germination was studied and it was found that the fields of Nagda town were not appropriate for seed germination. Rate of germination was found poor in comparison to other field.

\section{RECOMMENDATIONS}

There should be a policy regarding the pollution. Rate of release of carbon di sulphide shoud be minimize to improve the entire environment. 


\section{ACKNOWLEDGEMENT}

- Author is thankful to Dr.K K Kumbhkar Professor in Botany Govt. College Nagda.

- Research team of my students.

- Team Govt Girls PG College Ujjain (M P)

\section{REFERENCES}

1. "Carbon Disulfide report from IHS Chemical". Retrieved June 15, 2013.

2. "Chemical profile: carbon disulfide from ICIS.com". Retrieved June 15, 2013.

3. Werner, H. (1982). "Novel Coordination Compounds formed from CS2 and Heteroallenes". Coordination Chemistry Reviews 43: 165-185. doi:10.1016/S00108545(00)82095-0.

4. Smeulders, MJ.; Barends, TR.; Pol, A.; Scherer, A.; Zandvoort, MH.; Udvarhelyi, A.; Khadem, AF.; Menzel, A.; Hermans, J.; Shoeman, RL.; Wessels, HJ.; Van den Heuvel, LP.; Russ, L.; Schlichting, I.; Jetten, MS.; Op den Camp, HJ. "Evolution of a New Enzyme for Carbon Disulphide Conversion by an AcidothermophilicArchaeon" Nature, 2011, 487, 412-416. doi:10.1038/nature10464

5. Ochiai, Bungo; Endo, Takeshi "Carbon dioxide and carbon disulfide as resources for functional polymers" Progress in Polymer Science (2005), 30, 183215. doi:10.1016/j.progpolymsci.2005.01.005

6. Greenwood, Norman N.; Earnshaw, Alan (1997). Chemistry of the Elements (2nd ed.). Butterworth-Heinemann. ISBN 0080379419.

7. Worthing, C. R.; Hance. R. J. (1991). The Pesticide Manual, A World Compendium (9th ed.). British Crop Protection Council.ISBN 9780948404429.

8. "Carbon Disulfide". Akzo Nobel.

9. Park, T.-J.; Banerjee, S.; Hemraj-Benny, T.; Wong, S. S. (2006). "Purification strategies and purity visualization techniques for single-walled carbon nanotubes". Journal of Materials Chemistry 16 (2): 141-154. doi:10.1039/b510858f.

10. Park, T.-J.; Banerjee, S.; Hemraj-Benny, T.; Wong, S. S. (2006). "Purification strategies and purity visualization techniques for single-walled carbon nanotubes". Journal of Materials Chemistry 16 (2): 141-154. doi:10.1039/b510858f.

11. BUYANOVSKY,G.A and G.H. wagner. 1983 'Annual cycle of carbon di oxide level in soil air' Soil Sci Soc. A MER j. , 47:1139-45

12. BALESDENT J. G.H. WAGNER AND A. MARIOTTI 1988 "Soil organic matter turnover in long term field experiments as revealed by carbon -13 natural abundance 'Soil Sci. Soc Amer. J.52:118-24. 